YEARBOOK

of ANTITRUST

and REGULATORY

STUDIES

www.yars.wz.uw.edu.pl
Peer-reviewed scientific periodical, focusing on legal and economic issues of antitrust and regulation. Creative Commons Attribution-No Derivative Works 3.0 Poland License.

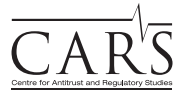

Centre for Antitrust and Regulatory Studies, University of Warsaw, Faculty of Management www.cars.wZ.uw.edu.pl

\title{
Insights from the Slovak Hybrid Mail Services Case. Case Comment to the Judgement of the General Court of 25 March 2015 and Order of Court of Justice of the EU of 30 June 2016 Slovenská pošta v Commission (Cases T-556/08, C-293/15P)
}

\author{
by
}

Karolis Kačerauskas*

\section{CONTENTS}

I. Introduction

II. Facts of the case

III. Case comments

1. Failure to meet the demand: the problem of causal link

2. Failure to meet the demand: the notion of demand

3. Legal test applicable in cases concerning extension of dominant position by State measures

IV. Conclusions

Key words: dominant position; postal sector; statutory monopoly.

JEL: K21

\section{Introduction}

The Slovak hybrid mail services case (or Slovenska posta case) is truly unique in EU jurisprudence. Within the last decade, the European Commission rarely applied Article 106(1) in conjunction with Article 102 TFEU to challenge

* Mykolas Romeris University, Vilnius, Lithuania, e-mail: karolis.kacerauskas@ellex.lt. Article received: 20 February 2017, accepted: 1 March 2017. 
competition distortions in individual cases. Thus Slovenska posta constitutes one of the rare examples of such enforcement. Slovenska posta also constitutes a very rare example of a judicial review of Commission decisions based on Article 106(1) and 102 TFEU. Slovenska posta is only the second case when European courts were called upon to review the application of Article 106(1) and 102 TFEU by the Commission and the first when the judicial review was conducted over a Commission decision regarding "failure to meet the demand".

Indeed, since 1989-1990 (when the Commission commenced to apply Article 106(1) and 102 TFEU to challenge competition distortions introduced by the Member States) and until 2014, when the Court of Justice adopted its decision in Greek lignite (DEI) case ${ }^{1}$, none of the Commission decisions was reviewed by EU courts. Such lack of appeals resulted in a rather strange situation under which the Commission and CJEU developed their own jurisprudence on the application of Article 106(1) and 102 TFEU and occasionally interpreted the same legal criteria differently. In this regard, a court review in Slovenska posta was eagerly awaited in the hope it would reconcile these diverging positions and provide more clarity on the application of Article 106(1) and 102 TFEU.

\section{Facts of the case}

The Slovenska posta case originated in 2008, when the Commission adopted an infringement decision ${ }^{2}$ challenging the decision of the Slovak government to extend statutory monopoly of the postal company into hybrid mailing services. This decision was challenged on the basis of two grounds: 1) failure to meet the demand by Slovenska posta; and 2) illegal extension of a dominant position by State measures.

Hybrid mailing services are usually required by clients requiring to deliver large quantities of letters (usually invoices). Normally, clients supply service providers with electronic files, which are printed, enveloped and delivered to addresses specified by the client. Having conducted the investigation, the Commission concluded that following the extension of the monopoly, Slovenska posta provided clients with hybrid mail services (i.e. demand for services as such was satisfied). Nevertheless, Slovenska posta did not offer

1 CJ judgment of 17.07.2014, Case C-553/12 P Commission v Dimosia Epicheirisi Ilektrismou AE (DEI), ECLI:EU:C:2014:2083.

${ }^{2}$ Decision of the European Commission of 7.10.2008, COMP/39.562, Slovakian Law on Hybrid Mail Services, Re [2009] 4 C.M.L.R. 13. 
two specific features of hybrid mail services which were previously offered by private companies. Slovenska posta failed to 1) provide electronic reports on delivery of postal items; and 2) deliver mail items 7 days a week. Failure to provide such services by Slovenska posta was sufficient for the Commission to adopt an infringement decision in $2008^{3}$.

\section{Case comment}

The General Court (hereinafter, GC) ${ }^{4}$ and the Court of Justice (hereinafter, CJ) ${ }^{5}$ decisions in Slovenska posta should be primarily praised for their explanations on the legal test which should apply in "failure to meet the demand" cases. It also shone light on legal tests applicable in cases when state measures allow to establish, maintain or expand a dominant position of undertakings having special relations with the State.

\section{Failure to meet the demand: the problem of a causal link}

The general idea that failure to meet the demand available on the market could amount to an infringement of Article 106(1) and 102 TFEU can be traced back to the Commission decision in Dutch Courier Services ${ }^{6}$ and Spanish post $^{7}$ adopted in 1989-1990. In those cases, the Commission suggested that an infringement takes place when the establishment of a monopoly deprives customers of services previously offered on the market. Nevertheless, the conceptual explanation for such type of infringement was formulated by CJ in Höfner case in $1991^{8}$. According to the CJ, an infringement of Article 106(1) and 102 TFEU could take part when an undertaking entrusted with exclusive rights "is manifestly not in a position to satisfy the demand prevailing

\footnotetext{
3 Ibidem.

4 GC judgement of 25.03.2015, Case T-556/08 Slovenska posta v Commission, ECLI:EU:T:2015:189.

5 CJ order of 30.06.2016, Case C-293/15 P Slovenska Posta AS v Commission, ECLI:EU:C:2016:511.

${ }^{6}$ Decision of European Commission of 20.12.1989, 90/16/EEC concerning the provision in the Netherlands of express delivery services, OJ 1990 L 10, 12.01.1990, p. 47-52.

7 Decision of European Commission of 1.08.1990, 90/456/EEC, concerning the provision in Spain of international express courier services, OJ 1990 L 233, 28.08.1990, p. 19-23.

8 CJ judgement of 23.04.1991, Case C-41/90 Klaus Höfner and Fritz Elser v Macrotron GmbH, ECLI:EU:C:1991:161, para. 30.
} 
on the market for activities of that kind"9. In such cases, the liability of the State under Article 106(1) could be invoked, taking into account that the State "creates a situation in which a public employment agency cannot avoid infringing Article [102]"10. Such legal test formulated in Höfner suggests that an infringement of Article 106(1) and 102 TFEU could be invoked only in cases in which there is a causal link between State actions and failure to meet the demand by the holder of monopoly rights.

In failure to meet the demand cases there are always two actors who could potentially be liable for the failure. Such failure could be attributed to the State, which created a legal monopoly, and/or an inefficient holder of monopoly rights who lacks proper incentives and efficiency to respond to the demand prevailing on the market.

Interestingly, for more than two decades following Höfner (i.e. until the Slovenska posta case) case law still lacked proper explanation on the causal link between State actions and failure to meet the demand which should be proven in such type of cases.

The legal test formulated by the CJ in Höfner argues that the State measure should place an undertaking in such a situation, where it "cannot avoid infringing Article [102]"11. Such test generally suggests that the liability of the State in failure to meet the demand cases could arise only in case the demand cannot be satisfied irrespective of efforts made by the holder of monopoly rights. In other words, an infringement of Article 106(1) and 102 TFEU could be invoked only in such cases, when the liability for failure to meet the demand could be attributed solely to the State which created such legal monopoly that even the most efficient operator would fail to meet the demand prevailing on the market. Such a strict legal test was followed by the CJEU in subsequent Job Centre II $^{12}$ and Carra ${ }^{13}$ cases. Although in Albany ${ }^{14}$, Pavlov ${ }^{15}$, Ambulanz Glocker $^{16}$ and $A G 2 R^{17}$ cases the Court showed some signs that the CJ could

\footnotetext{
9 C-41/90 Klaus Höfner, para. 31.

10 C-41/90 Klaus Höfner, para. 26.

11 C-41/90 Klaus Höfner, para. 26.

12 CJ judgement of 11.12.1997, Case C-55/96 Job Centre Coop. arl, ECLI:EU:C:1997:603.

13 CJ judgement of 8.06.2000, Case C-258/98 R. v Criminal Proceedings against Carra and Others, ECLI:EU:C:2000:301.

14 CJ judgement of 21.09.1999, C-67/96 Albany International BV v Stichting Bedrijfspensioenfonds Textielindustrie, ECLI:EU:C:1999:430.

${ }_{15}$ CJ judgement of 12.09.2000, Joined Cases C-180-184/98 Pavlov and Others $v$ Stichting Pensioenfonds Medische Specialisten, ECLI:EU:C:2000:428.

16 CJ judgement of 25.10.2001, C-475/99 Ambulanz Glöckner v Landkreis Südwestpfalz, ECLI:EU:C:2001:577.

17 CJ judgement of 3.03.2011, C-437/09 AG2R Prévoyance v Beaudout Père et Fils Sarl, ECLI:EU:C:2011:112.
} 
be ready to accept the existence of an infringement even when the State and the holder of monopoly rights would be jointly liable for the failure to meet the demand.

At the same time the Commission's practice clearly accepted a joint liability test, suggesting that "failure to meet the demand" should be analysed from the perspective of consequences. When demand prevailing on the market subjected to a statutory monopoly remains unsatisfied, the infringement could be declared irrespective of whether such a situation was caused by the State or by inefficient holder of monopoly rights. Such joint liability theory was applied by the Commission in Dutch Courier Services ${ }^{18}$, Spanish post ${ }^{19}$, suggested to the CJ in Höfner case ${ }^{20}$, and subsequently applied in Italian $G S M^{21}$, Spanish $G S M^{22}$ and Slovenska posta ${ }^{23}$ cases. Interestingly, the Commission insisted on applying such joint liability theory irrespective from the fact that in the Höfner case, the CJ quite explicitly departed from the joint liability theory, suggested there by the Commission.

The Slovenska posta case managed to reconcile different positions of the $\mathrm{CJ}$ and the Commission, leaving little room for any further debates.

As noted above, the Slovenska posta case concerned an extension of monopoly into hybrid mail services, which had previously been provided by private companies. Following monopolisation, hybrid mail services as such have been provided. Nevertheless the customers were no longer offered very specific features of such services, namely the delivery of postal items 7 days a week and the submission of electronic reports on delivery of postal items, both of which were previously offered by private operators.

Considering that such additional services had been provided by private market operators, it was rather clear that Slovenska posta could in principle offer such services by making additional investment. Such circumstance manifestly suggested that the failure to meet the demand considered in Slovenka posta depended mostly on the inefficiency of the postal company,

18 Decision of European Commission of 20.12.1989, 90/16/EEC concerning the provision in the Netherlands of express delivery services, OJ L 10, 12.1.1990, p. 47-52.

19 Decision of European Commission of 1.08.1990, 90/456/EEC concerning the provision in Spain of international express courier services, OJ L 233, 28.8.1990, p. 19-23.

20 C-41-90 Klaus Höfner.

21 Decision of European Commission of 4.10.1995, 95/489/EC concerning the conditions imposed on the second operator of GSM radiotelephony services in Italy, OJ L 280, 23.11.1995, p. 49-57.

22 Decision of the European Comission of 18.12.1996, 97/181/EC concerning the conditions imposed on the second operator of GSM radiotelephony services in Spain, OJ L 76, 18.3.1997, p. 19-29.

${ }^{23}$ Decision of the European Comission of 7.10. 2008, COMP/39.562, Slovakian Law on Hybrid Mail Services, Re [2009] 4 C.M.L.R. 13. 
rather than the State, which extended the legal monopoly. Nevertheless, such fact did not stop the Commission from assuming a joint liability of the State and the holder of monopoly rights ${ }^{24}$.

In reviewing the Slovenska posta case, the General Court followed the joint liability theory applied by the Commission. Although the decision adopted by the court commenced its analysis by mentioning the Höfner case, which apparently suggests that a determination of direct causal link between the State measures and failure to meet the demand should be established, the subsequent explanations clearly suggest that the Höfner case was mentioned merely as an example illustrating that failure to meet the demand may lead to an infringement of Article 106(1) and 102 TFEU $^{25}$.

This becomes clear in subsequent sections, where the court concluded that Article 106(1) applied in conjunction with Article 102 may be infringed once the holder of monopoly rights "is led" to an infringement of Article 102, which corresponds to the modern legal test accepted by the CJEU in Greek lignite ${ }^{26}$. Such legal test presupposes the existence of joint liability, which contrasts with the "cannot avoid infringement" test employed in Höfner, presupposing the sole liability of the State.

And finally, the determination of the GC to accept the joint liability test could be derived from the fact that the court upheld the presence of an infringement irrespective of clear indications that the establishment of monopoly was not the sole and primary cause of failure to meet the demand. It was rather obvious that such minor additional services as a 7-days a week delivery and track-and-trace options could be provided by an efficient holder of monopoly rights, which was confirmed by the provision of such services by private companies earlier.

The decision of the GC was appealed by the Slovak government to the CJ. The claimant referred to the Höfner case, suggesting that an infringement of Article 106(1) and 102 TFEU could take part only when the State is solely liable for failure to meet the demand, i.e. irrespective of the efforts by the holder of monopoly rights, the demand could not be satisfied ${ }^{27}$. Nevertheless, the CJ specifically rejected such a position, explaining that "the case-law covers all cases of manifest inability to satisfy the demand for certain activities, and not only those where the inability is "structural" 28.

${ }^{24}$ Decision of the European Comission of 7.10. 2008, COMP/39.562, Slovakian Law on Hybrid Mail Services, paras 149-155.

25 T-556/08 Slovenska posta v Commission, para. 315.

26 C-553/12 P Commission v Dimosia Epicheirisi Ilektrismou AE (DEI).

27 C-293/15 P Slovenska Posta AS, para. 24.

28 C-293/15 P Slovenska Posta AS v Commission, paras. 36-37. 
Such straightforward explanations provided by the CJ in Slovenska posta managed to reconcile divergent views of the Commission and the CJ, which lasted for more than two decades. Slovenska posta made it clear that failure to meet the demand should be analysed from the perspective of consequences - in case when some demand on the market remains unsatisfied and the State simultaneously prevents customers from seeking alternative supplies, this is sufficient for the establishment of State liability under Article 106(1) and 102 TFEU.

\section{Failure to meet the demand: the notion of demand}

As noted above, the Höfner test enables invoking State liability in case the holder of monopoly rights "is manifestly not in a position to satisfy the demand prevailing on the market for activities of that kind" 29 . The application of such a legal test requires understanding of at least two elements. Firstly, it is necessary to understand what gravity of failure is required to conclude the presence of a "manifest" failure to meet the demand. Secondly, it is necessary to understand the context in which the failure to meet the "demand prevailing on the market" should be analysed. In particular, it needs understanding whether satisfaction of demand should be assessed from the perspective of the relevant market, the perspective of the type of services, the perspective of each individual customer, etc.

The question of the appropriate perspective is very important as a change of perspective may deliver totally different results of the assessment. For example let us assume that the company providing public transportation services fails to run services suitable for the disabled. In case we would consider "failure to meet the demand" from the perspective of society in general, such failure most possibly would not lead to a manifest failure to meet the demand prevailing on the market because disabled people statistically constitute only a small portion of the customers. Nevertheless, in case we would analyse the same failure from the perspective of disabled customers, we would definitely conclude that a public transportation company failed to meet the demand as the service needed was not offered.

Until Slovenska posta, there was an obvious lack of clarity how the above two elements should be interpreted.

The position of the CJEU with regards to the interpretation of the above elements had mostly been formulated in the early case practice - Höfner and Job Centre II cases resolved in 1991 and 1997. Both of these cases concerned

29 C-41-90 Klaus Höfner, para. 31. 
rather extreme examples of failure to meet the demand, where the failure was obvious. Such case law induced some commentators to consider that an infringement of Article 106(1) and 102 could take part only in marginal failure to meet the demand cases $^{30}$. Yet some room for a debate remained over the question if in Höfner and Job Centre II the CJ used the notion of "manifest" failure referring to the specific circumstances of the case or established the necessity to prove a certain gravity of failure. Only in subsequent Pavlov, Ambulanz Glockner and AG2R, the CJ provided some hints suggesting that the gravity of failure (i.e. "manifest") should amount to a separate legal criterion. Nevertheless, the definition of gravity required to establish the infringement remained unclear.

The CJ practice also did not provide sufficient clarity with regard to the perspective which should be taken to decide whether the holder of monopoly rights failed to meet the demand prevailing on the market. Early CJ practice formulated in Höfner, Job Centre II and Pavlov seemed to suggest that the assessment should be performed from the perspective of "each service" failing within the scope of a monopoly (which is narrower than the relevant market but wider than the needs of each individual customer). Only in the $A G 2 R$ case, the CJ provided some hints that the assessment should be made from the perspective of interests of "each individual customer".

While the CJ struggled with the formulation of an appropriate legal test, the Commission consistently applied a low standard for State liability under Article 106(1) and 102 TFEU. As suggested by the Commission decisions in Dutch Courier Services ${ }^{31}$, Spanish post ${ }^{32}$, Italian GSM $^{33}$ and Spanish GSM ${ }^{34}$, failure to meet the demand could be associated with a simple failure to provide the service, rather than extreme failure. Moreover, the Commission always conducted its analysis from the perspective of interests of each particular customer, rather than the relevant market or the scope of monopoly.

30 E.g. "by referring in Höfner to an undertaking manifestly not in a position to satisfy demand the Court made it clear that it exercises only marginal review of the legality of monopolies“. Opinion of AG Jacobs in CJ judgement of 21.09. 1999, Case C-67/96 Albany International BV v Stichting Bedrijfspensioenfonds Textielindustrie, ECLI:EU:C:1999:430, paras 408, 409.

31 Decision of European Commission 90/16/EEC concerning the provision in the Netherlands of express delivery services.

${ }^{32}$ Decision of European Commission 90/456/EEC concerning the provision in Spain of international express courier services.

33 Decision of European Commission 95/489/EC concerning the conditions imposed on the second operator of GSM radiotelephony services in Italy.

${ }^{34}$ Decision of the European Comission 97/181/EC concerning the conditions imposed on the second operator of GSM radiotelephony services in Spain. 
As noted above, Slovenska posta case concerned failure of the statutory post monopoly to provide two specific features of hybrid mail services: (i) track-and-trace service enabling to receive electronic reports on delivery of postal items; (ii) delivery of mail items 7 days a week. Demand for such specific features of the hybrid mail service was very different. Major clients attached high importance to electronic reports on delivery of letters, as such reports are necessary for the proper invoicing process. At the same time delivery of letters 7 days week was considered as a less important additional feature ${ }^{35}$, which even made the GC ponder if such services were needed by some customers at all. Nevertheless, both the Commission and the GC accepted that failure to provide each of those services with very different demand constituted infringement of Article 106(1) and 102 TFEU. In its turn, the CJEU upheld this decision by rejecting the appeal of the Slovak government suggesting that presence of demand was not proven with sufficient evidence ${ }^{36}$.

In this regard, the Slovenska posta decision suggests several conclusions. Firstly, even though the legal test formulated in Höfner case remains valid and suggests the presence of an infringement only in cases of "manifest" failure to meet the demand, the legal standard applicable for finding the infringement is much lower. An infringement could be established when a service needed by some customers is not provided. Secondly, for the presence of failure it is sufficient to establish that the holder of monopoly rights failed to introduce specific features of the service, i.e. even when services subject to the legal monopoly in general are provided perfectly. Thirdly, Slovenska posta made it clear that the assessment of failure to meet the demand prevailing on the market should be viewed from the perspective of each individual customer (e.g. in Slovenska posta nthe ecessity of 7-day delivery was based on the alleged needs of a single customer). Following Slovenska posta, it could be clearly concluded that the State liability under Article 106(1) and 102 TFEU could be established when there is at least a single customer having very specific needs for monopolized services and such needs are not satisfied by the holder of a statutory monopoly.

\section{Legal test applicable in cases concerning extension of dominant position by State measures}

It is generally accepted in the CJEU jurisprudence since Sacchi ${ }^{37}$ that Article 106(1) and 102 TFEU as such does not prevent Members States from

\footnotetext{
35 T-556/08 Slovenska posta, paras 322-355.

36 C-293/15 P Slovenska Posta AS, paras 25, 39.

37 ECJ judgement of 30.04.1974, Case 155/73 Italy v Sacchi, ECLI:EU:C:1974:40.
} 
establishment of a dominant position by granting exclusive rights. Nevertheless, the subsequent CJEU practice also suggests that having established a logical link between granting exclusive rights and a reduction of effectiveness of Article 102 TFEU, such a grant of exclusive rights could be perceived as an infringement of Article 106(1) and 102 TFEU.

When it concerns the extension of a dominant position by State measures, the predominant legal test has been formulated by the CJ in $G B-I N N O-B M$ case $^{38}$. GB-INNO-BM test is based on the following logical structure. Firstly, it is necessary to determine anti-competitive consequences caused by the introduction of State measures. Secondly, it is necessary to consider whether analogous anticompetitive consequences could have been achieved by the undertaking by abusing its dominant position. Thirdly, the State shall be held liable under Article 106(1) and 102 TFEU when State measures place undertakings in a position which they could not attain by their own conduct without infringing Article 102. In other words, the State is liable for reduction of effectiveness of Article 102 TFEU in case the State measures entitle an undertaking to enjoy desired anti-competitive effects without having to engage in actions which could be caught under Article 102 TFEU $^{39}$. Such legal test formulated in $G B-I N N O-B M$ was explicitly applied by the Commission in the Slovenska posta case ${ }^{40}$.

In this regard, it should be noted that after the adoption of the Commission decision in 2008, in 2014, the CJ issued its landmark decision in the Greek lignite case ${ }^{41}$, which constituted the first judicial review of Commission decisions based on Article 106(1) and 102 TFEU. In Greek lignite, the CJ accepted the presence of State liability for the extension of a dominant position by State measures. Nevertheless, the presence of an infringement was declared on the basis of an equal opportunities test, which was quite different from the test established in GB-INNO-BM. In this regard, the GC decision in Slovenska posta was largely awaited to understand whether the contemporary case law shall rely on the equal opportunities test or the GB-INNO-BM legal test, which was employed by the Commission in Slovenska posta case.

The GC in Slovenska posta case quite naturally decided to follow the reasoning provided by the $\mathrm{CJ}$ in the Greek lignite case in 2014, rather than to uphold the GB-INNN-BM test employed by the Commission. In this regard, the GC repeated various considerations from Greek lignite ${ }^{42}$ and concluded that:

38 CJ judgement of 13.12.1991, Case C-18/88 Régie des télégraphes et des téléphones v GB-Inno-BM SA., ECLI:EU:C:1991:474.

39 C-18/88 Régie des télégraphes et des téléphones v GB-Inno-BM SA., paras. 18-21.

40 Decision of the European Comission, COMP/39.562, para. 116.

41 C-553/12 P Commission v Dimosia Epicheirisi Ilektrismou AE (DEI).

42 T-556/08 Slovenska posta, paras 97-103. 
"102. (...) infringement of Article 86(1) EC in conjunction with Article 82 EC may be established irrespective of whether any abuse actually exists. All that is necessary is for the Commission to identify a potential or actual anti-competitive consequence liable to result from the State measure at issue. Such an infringement may thus be established where the State measure at issue affects the structure of the market by creating unequal conditions of competition between companies, by allowing the public undertaking or the undertaking which was granted special or exclusive rights to maintain (for example by hindering new entrants to the market), strengthen or extend its dominant position over another market, thereby restricting competition; it is not necessary to prove the existence of an actual abuse.

103. Accordingly, it is sufficient to show that that potential or actual anti-competitive consequence is liable to result from the State measure at issue, and it is not necessary to identify an abuse other than that which results from the situation brought about by the State measure at issue."

The analysis of the GC decision suggests that the equal opportunities test, which was articulated by the CJEU in Greek lignite and followed by the GC in Slovenska posta, significantly expanded State liability under Article 106(1) and 102 TFEU. Indeed, the equal opportunities test elaborated in Slovenska posta seems to suggest that an infringement of Article 106(1) and 102 TFEU could be implied in any situation, where the State decides to intervene in the market and provide competitive advantage for State-owned companies or companies holding special or exclusive rights. Such legal standard does not require proving any hypothetical abuse of dominant position, which is required by the logical structure of the $G B-I N N-B M$ test.

Nevertheless, such wide interpretation of the GC ruling implies some conceptual difficulties. An infringement of Article 106(1) and 102 TFEU requires a rational explanation as to how the measures introduced by the State resulted in a reduction of effectiveness of the prohibition of dominant position established in Article 102 TFEU. That means that there should be some causal link between competition distortions and abuse of a dominant position.

In this regard the lacking legal link could be discovered by referring back to the analysis of Greek lignite decision, which clearly inspired GC in Slovenska posta. It should be noted that the CJ reasoning in Greek lignite dlargely relied on the Connect Austria case ${ }^{43}$, which also implied an Article 106(1) and 102 TFEU infringement on the basis of the equal opportunities theory.

As suggested by the CJ in Connect Austria, having received competitive advantage, an undertaking having special relations with the State will inevitably perform some unidentified abusive actions because it will be thus enabled to establish, maintain or expand its dominant position. Greek lignite optimized the

43 CJ judgement of 22.05.2003, Case C-462/99 Connect Austria Gesellschaft fur Telekommunikation GmbH v Telekom-Control-Kommission, ECLI:EU:C:2003:297. 
legal test deployed in Connect Austria and does not require any discussion on the unidentified abusive actions, assuming that in most cases such actions will be present. Nevertheless, the absence of necessity to discuss abusive actions does not mean that the CJ in Greek lignite or the GC in Slovenska posta wanted to imply that an infringement of Article 106(1) and 102 TFEU could be invoked without any logical link between the State measures and abusive actions.

To maintain conceptual grounds of an Article 106(1) and 102 TFEU infringement, it should be admitted that such a logical link exists in the reasoning provided by the CJEU in Greek lignite and followed by the GC in Slovenska posta. Although the abusive actions should not be necessarily discussed, the equal opportunities test applied in Slovenska posta did not eliminate the necessity to show the causal link between competition distortions and the reduction of effectiveness of Article 102 TFEU. Hence, at least theoretically, a distortion of equal opportunities could be justified having proved that benefits received from the State were so isolated that such benefits did not allow to establish, maintain or expand a dominant position, thus the effectiveness of Article 102 TFEU was not reduced.

Notably, the decision of the GC in Slovenska posta was appealed to the CJ. The CJ rejected this appeal without providing any explanation on the application of equal opportunities or GB-INNO-BM tests. The CJ accepted that the expansion of Slovenska posta monopoly infringed Article 106(1) and 102 TFEU due to the failure to meet the demand. Respectively, the CJ did not find the necessity to analyse pleas concerning the extension of the dominant position submitted by the Slovak government ${ }^{44}$.

\section{Conclusions}

The GC and CJ decisions in Slovenska posta are truly significant for the interpretation of the prohibition established in Article 106(1) and 102 TFEU. Slovenska posta was the first instance when a Commission decision in a "failure to meet the demand" case underwent a full judicial review. This review allowed to reconcile different interpretations of legal requirements, which need to be proven in failure to meet the demand cases, suggested by the practice of the CJEU and the Commission. Slovenska posta made it clear that (i) failure to meet the demand should be analysed from the perspective of consequences, i.e. in case the demand remains unsatisfied, an infringement of Article 106(1) and 102 TFEU could be invoked without any further analysis of the person

44 C-293/15 P Slovenska Posta AS v Commission, paras 46-47. 
liable for such a situation - the State or an ineffective holder of monopoly rights; (ii) "manifest" failure to meet the demand does not require proving certain graveness of failure; "manifest" failure to meet the demand could be also declared in case of "simple" or "obvious" failure; (iii) failure to meet the demand prevailing on the market should be analysed from the perspective of each customer, hence an infringement could be implied in case there is at least one customer who is not offered goods and/or services needed and is simultaneously prohibited by the State measures from seeking alternative supplies.

The decisions in Slovenska posta also made it clear that modern jurisprudence prefers the equal opportunities doctrine, rather than the $G B-I N N O-B M$ hypothetical abuse test, to imply an infringement of Article 106(1) and 102 TFEU in cases concerning the establishment, maintenance or expansion of a dominant position. It should be admitted here that the GC in Slovenska posta followed the reasoning provided in the CJ decision in Greek lignite and hence does not add any significant details to the interpretation of the equal opportunities doctrine formulated by the CJ. 